\title{
REVISTA BIO CIENCIAS
}

\section{Presence of Coliforms bacteria, fungi and aflatoxins in medicinal plants marketed in Nayarit, Mexico.}

\section{Presencia de bacterias coliformes, hongos y aflatoxinas en hierbas medicinales comercializadas en Nayarit, México.}

Bueno-Durán, A. Y. ${ }^{2,3}$, Barcelos-García, R. G. ${ }^{2}$, Ventura-Ramón, G. H. ${ }^{2,3}$, Toledo-Ibarra, G. A. ${ }^{1,2}$, Navidad-Murrieta, $M . S^{2}{ }^{2}$ Zambrano-Soria, $M{ }^{2}$, Robles Pérez, $A . G^{3}{ }^{3}$, Girón-Pérez, M. I.,2*

${ }^{1}$ Universidad Autónoma de Nayarit. Secretaría de Investigación y Posgrado. Laboratorio de Inmunotoxicología. Cd de la Cultura Amado Nervo S/N. Tepic Nayarit, México. ${ }^{2}$ Centro Nayarita de Innovación y Transferencia de Tecnología A.C. Laboratorio Nacional de Investigación para la Inocuidad Alimentaria (LANIIA)-Unidad Nayarit. Calle tres S/N. Col. Cd Industrial, Tepic Nayarit, México. ${ }^{3}$ Universidad Autónoma de Nayarit, Unidad Académica de Ciencias Químico, Biológicas y Farmacéuticas. Cd de la Cultura Amado Nervo S/N. Tepic Nayarit, México.

Cite this paper/Como citar este artículo: Bueno-Durán, A. Y., Barcelos-García, R. G., VenturaRamón, G. H., Toledo-lbarra, G. A., Navidad-Murrieta, M. S., Zambrano-Soria, M., Robles Pérez, A. G., Girón-Pérez, M. I. (2019). Coliforms bacteria, fungi and aflatoxins detection in medicinal herbs marketed in Nayarit, Mexico. Revista Bio Ciencias 6(2), e636. doi: https://doi.org/10.15741/revbio.06.nesp.e636

\section{A B S T R A C T}

The consumption of medicinal plants has been currently increasing, either as alternative medicine (under the argument that "natural is innocuous") or as first-line medicine, due to the lack of health services; however, scientifically there is little certainty about the safety of these products, a situation that far from favoring the consumer's health, might put it at risk. Therefore, the aim of this work was to evaluate the presence of total and fecal coliforms, Escherichia coli, fungi and total aflatoxins in the most marketed medicinal plants in the city of Tepic, Nayarit, Mexico. Analyzed medicinal plants were the most commercialized for the autumn-winter and spring-summer seasons. The results showed that $51.8 \%$ of the analyzed samples were contaminated by total coliforms, $12 \%$ by fecal coliforms and $6 \%$ by $E$. coli. Regarding fungi, those of greatest presence were of the genus Aspergillus, identifying

Article Info/Información del artículo

Received/Recibido: December 14 2018.

Accepted/Aceptado: January $10^{\text {th }} 2019$.

Available on line/Publicado: April $12^{\text {nd }} 2019$.

\section{RES U MEN}

Actualmente el consumo de hierbas medicinales ha ido en aumento, ya sea como medicina alternativa (bajo el argumento de que lo "natural es inocuo") o como medicina de primera instancia, debido a la carencia de servicios de salud; sin embargo, científicamente existe poca certidumbre sobre la inocuidad de estos productos, situación que lejos de favorecer la salud del consumidor, puede poner en riesgo la misma. Por lo tanto, el objetivo de este trabajo fue evaluar la presencia de bacterias coliformes totales, fecales, Escherichia coli, hongos y aflatoxinas totales en las hierbas medicinales más comercializadas en la Ciudad de Tepic, Nayarit, México. Las hierbas medicinales analizadas fueron las de mayor comercialización para la temporada otoño-invierno y primavera-verano. Los resultados mostraron que el $51.8 \%$ de las muestras analizadas presentaron contaminación por coliformes totales, el $12 \%$ por coliformes fecales y el $6 \%$ por E. coli. Con respecto a los hongos, los de mayor presencia fueron del género Aspergillus, identificándose las especies $A$. niger, $A$. fumigatus y $A$. terreus. La presencia de aflatoxinas se encontraron en el $44.6 \%$ de las muestras analizadas y el 21.7 $\%$ presentaron niveles por arriba de los límites permisibles

\section{*Corresponding Author:}

Girón-Pérez, Manuel Iván. Universidad Autónoma de Nayarit, Secretaría de Investigacion y Posgrado, Avenida de la Cultura S/N, Col. Centro, C.P. 63000, Tepic, Nayarit., México. Phone: +52(311)211 8800, Ext.8922. E-mail: ivan_giron@hotmail.com 
the species $A$. niger, $A$. fumigatus, and $A$. terreus. Aflatoxins were found in $44.6 \%$ of analyzed samples and $21.7 \%$ showed levels above the permissible limits (>20ppb). The presence of this type of contaminants in medicinal plants evidenced bad practices in the handling of this type of products, and represented a risk for consumer's health, since the microorganisms detected in this work are potential pathogens, and in the case of mycotoxins, they are carcinogenic. Thus, a strict regulation in the management (cultivation, storage and commercialization) of this type of products is necessary to ensure their safety.

\section{KEY WOR D S}

Medicinal herbs, microbiological contamination, mycotoxins.

\section{Introduction}

Medicinal plants are considered as vegetables containing secondary metabolites, also called active principles, which are substances that act as pharmacological beneficial or harmful molecules on the organism (Martins \& S. 2018).

The use of plants with medicinal attributes were the first medicines to be empirically used for curing diseases affecting humans. This knowledge has been passed on for generations trough different cultures until our time (Devesa 2004; Marinoff 2006).

The World Health Organization estimates that the primary attention of health, up to $80 \%$ of the population in developing countries, is based on traditional medicine, by culture tradition or because there are no other options. While, as for developed countries, many people turn to several types of natural remedies because they think "natural" is synonym of innocuous (WHO, 2004; da-Silva et al., 2012; Luitel et al., 2014; Ávila, 2017). That is why, the consumption of medicinal plants has been increasing, even though it is not entirely regulated. In Mexico, medicinal plants are poorly regulated, since according to legislation, their approval consists in "just demonstrating that these remedies are safe and under no circumstances, assert any effectivity or therapeutic power against a specific disease" (Gómez, 2009). In general, these treatments are guaranteed only by tradition but lack of scientific support (Enríquez et al., 2005; (>20ppb). La presencia de este tipo de contaminantes en hierbas medicinales, evidencian malas prácticas en el manejo de este tipo de productos representando un riesgo para la salud del consumidor, ya que los microorganismos detectados en este trabajo son patógenos potenciales, y en el caso de las micotoxinas, son carcinogénicas, por lo que es necesaria una regulación estricta en el manejo (cultivo, almacenamiento y comercialización) de este tipo de productos que permitan asegurar su inocuidad.

\section{PALABRAS CLAVE}

Hierbas medicinales, contaminación microbiológica, micotoxinas.

\section{Introducción}

Las hierbas medicinales son consideradas como aquellos vegetales que contienen metabolitos secundarios, llamados principios activos, los cuales son sustancias que ejercen una acción farmacológica, beneficiosa o perjudicial sobre el organismo (Martins \& S. 2018).

El uso de hierbas con atributos medicinales fueron las primeras medicinas utilizadas en forma empírica para la cura de enfermedades que padecía el humano. Dichos conocimientos han sido transmitidos por generaciones a través de diferentes culturas hasta nuestros días (Devesa, 2004; Marinoff, 2006).

La Organización Mundial de la Salud estima que la atención primaria de salud, de hasta $80 \%$ de la población de los países en desarrollo, se basa en la medicina tradicional, por tradición cultural o porque no existen otras opciones. Mientras que, en los países desarrollados muchas personas recurren a diversos tipos de remedios naturales porque consideran que lo "natural" es sinónimo de inocuo (WHO, 2004; da-Silva et al., 2012; Luitel et al., 2014; Ávila, 2017). Por lo tanto, el consumo de hierbas medicinales ha ido en aumento, aunque su regulación no se encuentra del todo establecida. En México, las hierbas medicinales están poco reguladas, ya que, de acuerdo con la legislación, para su aceptación, "sólo debe demostrarse que dichos remedios son seguros y no debe bajo ninguna circunstancia, aseverar efectividad alguna o poder terapéutico contra una enfermedad específica" (Gómez, 2009). En general, estos tratamientos están avalados sólo por la tradición y no tienen un soporte experimental científico (Enríquez et al., 2005; Marinoff et al., 2009). Por otra parte, la Comisión Federal para la Protección contra Riesgos 
Marinoff et al., 2009). On the other hand, the Comision Federal para la Protección contra Riesgos Sanitarios (COFEPRIS) has subscribed a cooperation at international level, with a perspective until 2025, of efficiently easing the availability of these innocuous and high quality products, with the purpose of protecting public health (Gómez, 2009).

Another problem related to consumption and commercialization of medicinal plants, is the degree of innocuousness due to the presence of chemical contaminants (heavy metals, and pesticides) (Marinoff et al., 2009; Kishan et al., 2014; Kumar et al., 2015; Rodrigues et al., 2017) and biological contaminants (fungi, bacteria, and toxins) (Arias et al., 1999; Sánchez et al., 2006), mainly due to bad management of these products in any of the phases of the production-commercialization chain (cultivation, harvest, transportation, storing and sale) (Kneifel et al., 2002; Codex Alimentarius, 2014). In Mexico, it has been documented that more than $85 \%$ of the species commercialized in local markets and naturist stores are collected in the wild form; this method does not normally count on effective handling programs and lack of sufficient control by government (Bye \& Linares, 1990; Juárez-Rosete et al., 2013).

Among the main agents responsible for biological contamination in medicinal plants, bacteria, fungi, and toxic metabolites stand out. With respect to bacteria, the group of fecal coliforms, aside from being an indicator of fecal contamination, represents a health risk for consumers, since some types of bacteria in this group are considered to be the cause of serious diseases, like Escherichia coli enterohemorrhagic strain (EHEC), bacteria species causing hemorrhagic colitis and hemolytic-uremic syndrome (Momoh et al., 2011; Pullés 2014). Moreover, filamentous fungi, are cosmopolitan microorganisms but under certain conditions, they can produce toxic metabolites, called mycotoxins, which have toxic severe effects that are related to hepatic, renal, digestive, reproductive, immunosuppressive diseases, and to the developing of tumors (MarroquínCardona et al., 2014; Kabak \& Dobson 2015; Abrunhosa et al., 2016; Pemán \& Quindos 2016). For the reasons abovementioned, the presence of this type of contaminants in medicinal plants and herbal products represent a serious risk to consumers' health.

The aim of this research was to assess the presence of bacteria (total coliforms, fecal and Escherichia coli), fungi
Sanitarios (COFEPRIS) ha suscrito una cooperación a nivel internacional, que tiene como perspectiva hacia el año 2025 , facilitar la disponibilidad de estos productos de manera eficaz, de buena calidad e inocua, a fin de proteger la salud pública (Gómez, 2009).

Otro problema relacionado con el consumo y comercialización de hierbas medicinales es el grado de inocuidad debido a la presencia de contaminantes químicos (metales pesados, plaguicidas) (Marinoff et al., 2009; Kishan et al., 2014; Kumar et al., 2015; Rodrigues et al., 2017) y biológicos (hongos, bacterias, toxinas) (Arias et al., 1999; Sánchez et al., 2006), debido en gran medida al mal manejo de estos productos en cualquiera de los puntos de su cadena de producción-comercialización (cultivo, cosecha, transporte, almacenamiento y venta) (Kneifel et al., 2002; Codex Alimentarius, 2014). En México, se ha documentado que más del $85 \%$ de las especies que se comercializan en los mercados locales y tiendas naturistas provienen de la recolección silvestre, método que normalmente, no cuenta con programas de manejo efectivos y carecen de control suficiente por parte de dependencias gubernamentales (Bye \& Linares, 1990; Juárez-Rosete et al., 2013).

Dentro de los principales agentes responsables de la contaminación biológica en plantas medicinales, destacan las bacterias, los hongos y sus metabolitos tóxicos. En lo que respecta a las bacterias, el grupo de coliformes fecales, además de ser un indicador de contaminación fecal, representan un riesgo para la salud de los consumidores, ya que en este grupo de bacterias se consideran algunos tipos que son causantes de enfermedades graves, por ejemplo, Escherichia coli enterohemorrágica (EHEC), especie de bacteria causante de colitis hemorrágica y síndrome urémico hemolítico (Momoh et al. 2011; Pullés 2014). Por otra parte, los hongos filamentosos, son microorganismos cosmopolitas, muchos de ellos clasificados como patógenos oportunistas para humanos, pero que además bajo ciertas condiciones pueden producir metabolitos tóxicos, denominados micotoxinas, las cuales tienen efectos tóxicos severos que están relacionados con enfermedades hepáticas, renales, digestivas, reproductivas, inmunosupresoras, e incluso desarrollo de tumores (MarroquínCardona et al., 2014; Kabak \& Dobson, 2015; Abrunhosa et al. 2016; Pemán \& Quindos 2016). Por todo esto, la presencia de este tipo de contaminantes en plantas medicinales y productos herbolarios, representa un riesgo grave para la salud del consumidor.

Por lo anterior, el objetivo de la presente investigación fue evaluar la presencia de bacterias (coliformes totales, fecales y Escherichia coli), hongos y aflatoxinas totales 
and total aflatoxins in medicinal plants commercialized in Tepic city, Nayarit, Mexico.

\section{Material and Methods}

This research work was carried out in the city of Tepic, Nayarit, Mexico, which is located in western Mexico $\left(21^{\circ} 3059\right.$ and $\left.104^{\circ} 5339\right)$ at an altitude of 920 masl, with a warm sub-humid climate with rains in the summer.

The sampling of medicinal plants was realized inside the city (Figure 1). A total of 28 establishments (naturist stores) were previously located. Then, the people in charge of those establishments were invited to participate; they were asked, using a structured questionnaire, what type of medicinal plant was the most commercialized during the period of autumn-winter and spring-summer. en hierbas medicinales comercializadas en la Ciudad de Tepic, Nayarit, México.

\section{Material y Métodos}

La investigación se realizó en la ciudad de Tepic, Nayarit, México, la cual se localiza en el Occidente de México $\left(21^{\circ} 3059\right.$ y $104^{\circ} 53$ 39) a una altitud de 920 masl, con un clima cálido sub-húmedo con lluvias en verano.

El muestreo de hierbas medicinales se realizó en el centro de la Ciudad (Figura 1). Previamente se localizaron un total de 28 establecimientos. Posteriormente, se invitó a participar en el estudio a las personas responsables de atención al público en cada expendio, a los cuales se les preguntó, a través de un cuestionario estructurado, el tipo de hierba medicinal más comercializado en la temporada otoño-invierno y primavera-verano.

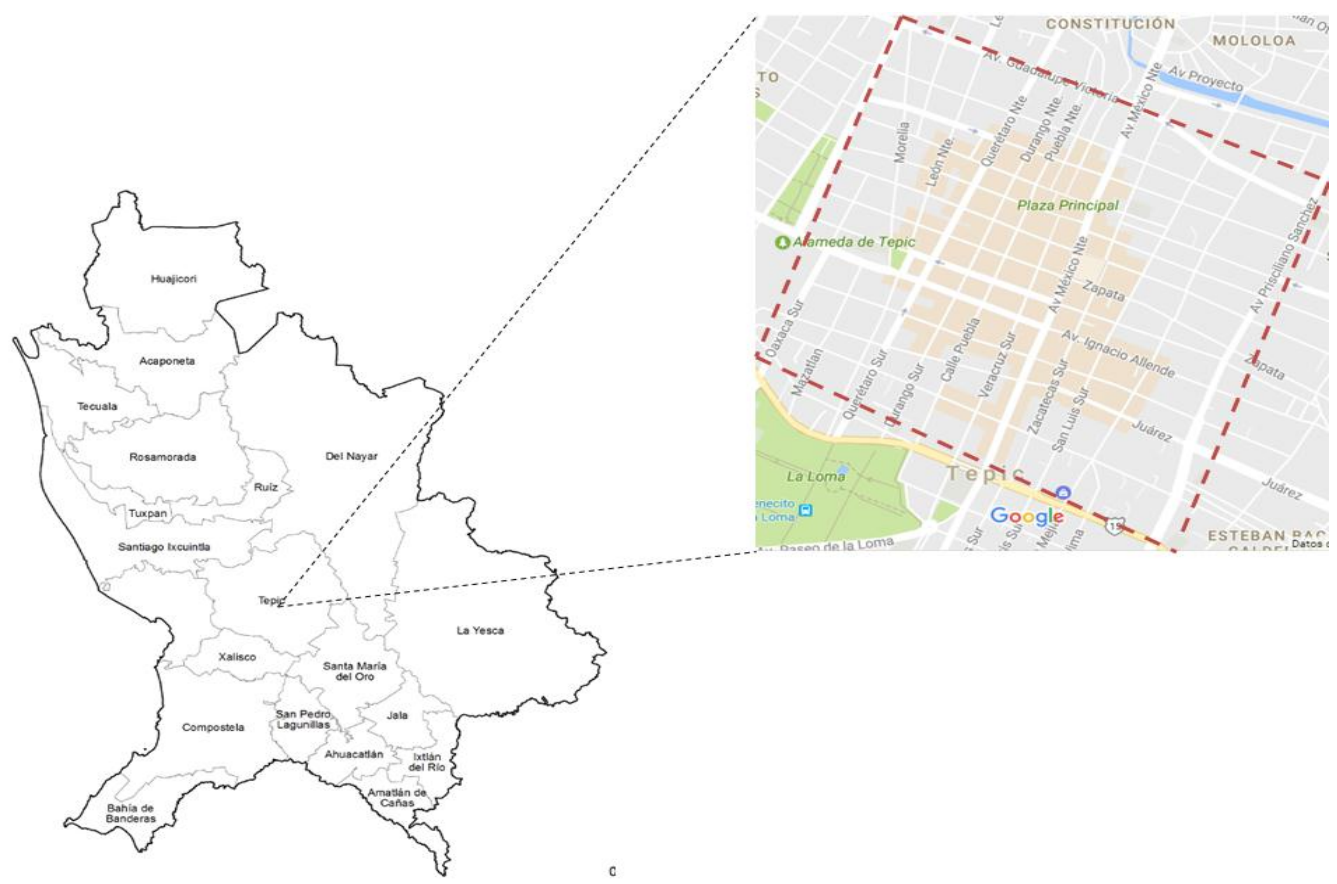

Figure 1. Geographic location of Tepic, Nayarit, Mexico. Tepic city is located in the central part of the state, at the extreme geographic coordinates $21^{\circ} 51$ 'and $21^{\circ} 24^{\prime}$ ' of north latitude and $104^{\circ} 34$ 'and $105^{\circ} 05^{\prime}$ ' of west longitude. The sampling area of medicinal herbs in the downtown Tepic, Nayarit, delimited by Victoria, Prisciliano Sánchez, Insurgentes Avenues and Juan Escutia Street.

Figura 1. Localización geográfica de Tepic Nayarit, México. La ciudad de Tepic se localiza en la parte central del estado, en las coordenadas geográficas extremas $21^{\circ} 51^{\prime}$ y $21^{\circ} 24^{\prime}$ de latitud norte y $104^{\circ} 34^{\prime}$ y $105^{\circ} 05^{\prime}$ de longitud oeste. El Área de muestreo de las hierbas medicinales en el centro de Tepic, Nayarit, delimitado por las Avenidas Victoria, Prisciliano Sánchez, Insurgentes y calle Juan Escutia. 
According to the results, 17 establishments accepted to participate. In each establishment, a sample was taken from one of the three most commercialized medicinal plants for each one of the seasons. As for the most commercialized plants during the period of autumn-winter, the sampling was realized from January to February and as for the plants during the period of spring-summer, the sampling was realized from August to September, 2016. The samples, collected in situ, were placed in sterile plastic bags for their transportation to the laboratory.

\section{Microbiological analysis}

For the microbiological analysis, the samples were prepared according to Norma Oficial Mexicana NOM-110SSA1-1994. For this, $10 \mathrm{~g}$ of each sample were weighed in aseptic conditions and placed in plastic bags with special filters for peristaltic homogenizer (Stomacher, BagMixer ${ }^{\circledR}$ 400 , St Nom France). Subsequently, $90 \mathrm{~mL}$ of phosphatebuffered saline (PBS) solution at $\mathrm{pH} 7.4$ were added and mixed for three minutes in the Stomacher. Finally, the solution was recovered in a sterile flask (work sample).

\section{Determination of total Coliforms bacteria (TC), fecal coliform bacteria (FC), and E. coli}

The determination of these bacterial groups was realized according to the most probable number (MPN) method described in CCAYAC-M-004/11.

Presumptive test: For each sample, a series of 3 tubes with $10 \mathrm{~mL}$ of sterile lauryl sulfate broth (LSB) was used, at a $1.5 \mathrm{X}$ concentration. Ten $\mathrm{mL}$ of the sample were added to the tubes; the determination was carried out by duplicate, in addition a positive control (tube with E. coli) and a negative control (tube with no bacterial inoculum) were used, in asepsis conditions. Later on, the tubes were taken to incubation at $35^{\circ} \mathrm{C}$ during a period of 24 to $48 \mathrm{~h}$.

Confirmative test: From each presumptively positive tube (production of gas in Durham tube), Three inoculations with bacteriological loop were transferred to the same number of tubes containing $5 \mathrm{~mL}$ of Brilliant-Green Bile Lactose Broth (BD Bioxon $®$ Mexico) at $2 \%$. Each determination was realized in duplicate; as well, a positive control (tube with E. coli) and a negative one (not inoculated tube) were used. Subsequently, a series of tubes was incubated at $35 \pm 0.5^{\circ} \mathrm{C}$ during $48 \mathrm{~h}$ for TC and at the same time, another series of tubes was incubated at $44.5 \pm 0.2{ }^{\circ} \mathrm{C}$ in bain-marie (VWR $\AA$ International,
Deacuerdoa los resultados de la encuesta, 17 establecimientos aceptaron participar. En cada establecimiento se tomó una muestra de cada una de las 3 hierbas de mayor comercialización para cada una de las temporadas. Para las hierbas de mayor comercialización durante la temporada otoño-invierno, el muestreo se realizó durante el periodo de enero-febrero y para las hierbas de primavera-verano, el muestreo se realizó en el periodo de agosto-septiembre de 2016. Las muestras recolectadas in situ, se colocaron en bolsas de plástico estériles para su transporte al laboratorio.

\section{Análisis microbiológico}

Para el análisis microbiológico, las muestras fueron preparadas de acuerdo a la Norma Oficial Mexicana NOM-110SSA1-1994. Para ello, se pesaron $10 \mathrm{~g}$ de cada muestra en condiciones asépticas y se colocaron en bolsas de plástico con filtros especiales para homogeneizador peristáltico (Stomacher, BagMixer ${ }^{8} 400$, St Nom France). Posteriormente, se agregaron $90 \mathrm{~mL}$ de solución reguladora de fosfato (PBS) a pH 7.4 y se mezclaron durante tres minutos en el Stomacher. Finalmente, se recuperó la solución en un frasco estéril (muestra de trabajo).

\section{Determinación de bacterias coliformes totales (TC), fecales (FC) y E. coli.}

La determinación de estos grupos bacterianos se realizó de acuerdo con el método de Número Más Probable (MPN) descrita en CCAYAC-M-004/11.

Prueba presuntiva: Para cada muestra se utilizó una serie de 3 tubos con $10 \mathrm{~mL}$ de Caldo Lauril Sulfato de Sodio (LSB) estéril a concentración 1.5 X. A los tubos se adicionó $10 \mathrm{~mL}$ de la muestra de trabajo; la determinación se realizó por duplicado, además se contó con un control positivo (tubo con E. coli) y un control negativo (tubo sin inóculo bacteriano), esto en condiciones de asepsia. Posteriormente, los tubos se llevaron a incubación a $35^{\circ} \mathrm{C}$ durante un lapso de 24 a $48 \mathrm{~h}$.

Prueba confirmativa: A partir de cada tubo presuntamente positivo (producción de gas en la campana de Durham), se transfirieron tres asadas a igual número de tubos que contenían $5 \mathrm{~mL}$ de Caldo Verde Brillante Bilis (BD Bioxon ${ }^{\circledR}$ México) al $2 \%$. Cada determinación se realizó por duplicado; además se contó con un control positivo (tubo con E. coli) y un control negativo (tubo sin inocular). Posteriormente, una serie de tubos se incubó a $35 \pm 0.5^{\circ} \mathrm{C}$ durante $48 \mathrm{~h}$ para TC y a la par, otra serie de tubos se incubó a $44.5 \pm 0.2^{\circ} \mathrm{C}$ en baño María (VWR $\circledast$ International, USA) para la determinación de FC. Para establecer el MPN/g, se 
USA) for the determination of FC. In order to establish the MPN/g, the corresponding tables established by CCAYAC-M-004/11 were reviewed.

For the confirmative test of $E$. coli, from each one of the samples which were positive to the FC test (formation of gas in Durham tube), three inoculations with bacteriological loop were transferred in the EC-MUG4 medium (4-methylumbelliferyl-beta-D-glucuronide) (Difco ${ }^{\mathrm{TM}}$, France) and was incubated at $44.5 \pm 0.2^{\circ} \mathrm{C}$ in bain-marie (VWR® International, USA) during $24 \mathrm{~h}$; a positive and negative controls were used. Concluding the period of incubation, the tubes were placed in an Ultra Violet light Chamber (365 nm) (ChemiDoc-It² Imager, UK), in which the presence of fluorescence was observed.

\section{Determination of fungi}

The determination of fungi was realized under the Norma Oficial Mexicana NOM-111-SSA1-1994. For this, $1 \mathrm{~mL}$ of the work sample was deposited in Petri dishes using a sterile pipette for each one of them, then $20 \mathrm{~mL}$ of sterile acidified Potato Dextrose Agar (PDA) (BD Bioxon $囚$, Mexico) with tartaric acid (Fermont, Mexico) were poured on them at $10 \%$. The dishes were homogenized; they were left to solidify by placing them on a cold horizontal surface. Candida spp. was used as a positive control and a not inoculated plate as negative control. Later on, the Petri dishes were incubated at room temperature for five days in darkness. Once the time passed, the morphology of the mycelium colonies was observed and described. The test was carried out by duplicate.

For the identification of potentially aflatoxigenic fungi, the colonies obtained in PDA agar were inoculated in the Czapeck Yeast Extract medium (CYA) (BD Bioxon®, Mexico) and Dichloran Rose Bengal Chloramphenicol Agar (DRBC) (Difco ${ }^{\mathrm{TM}}$, France) mediums, and were later taken to incubated at room temperature for five days in darkness. Once passed this time, the morphology of the obtained colonies was described and the microscopic structures were observed with lactophenol blue (Hycel, Mexico) at 40X. For the identification of the genera and species of the fungi, dichotomic criteria according to Koneman et al. (2008) were considered.

\section{Quantification of total aflatoxins (AF)}

Prior to the quantification of total aflatoxins $(\mathrm{AF})$, a methanolic extraction was performed. Briefly, $5 \mathrm{~g}$ of the samples revisaron las tablas correspondientes establecidas por la CCAYAC-M-004/11.

Para la prueba confirmativa de $E$. coli, de cada una de las muestras positivas a la prueba de FC (formación de gas en campana de Durham), se inocularon 3 asadas en el medio EC-MUG4 (4-metil-umbeliferil $\beta$-D-glucurónido) (Difco ${ }^{\mathrm{TM}}$, France) y se incubaron a $44.5 \pm 0.2^{\circ} \mathrm{C}$ en baño María (VWR® International, USA) durante $24 \mathrm{~h}$; se contó con un control positivo y un control negativo. Finalizado el periodo de incubación los tubos se colocaron en una cámara de luz ultravioleta (365 nm) (ChemiDoc-It ${ }^{2}$ Imager, UK), en la que se observó la presencia de fluorescencia.

\section{Determinación de hongos}

La determinación de hongos fue realizada bajo la Norma Oficial Mexicana NOM-111-SSA1-1994. Para ello, se depositó $1 \mathrm{~mL}$ de la muestra de trabajo en cajas de Petri utilizando para cada una de ellas una pipeta estéril, enseguida se vertieron $20 \mathrm{~mL}$ de Agar Papa Dextrosa (PDA) (BD Bioxon®, México) estéril acidificado con ácido tartárico (Fermont, México) al $10 \%$. Las cajas fueron homogeneizadas, se dejaron solidificar colocándolas sobre una superficie horizontal fría. Como control positivo, se utilizó Candida spp. y como control negativo una placa sin inocular. Posteriormente, las cajas se incubaron a temperatura ambiente durante 5 días en oscuridad. Una vez concluido este tiempo, se observó y describió la morfología de las colonias miceliales. El ensayo se realizó por duplicado.

Para la identificación de hongos potencialmente aflatoxigénicos, las colonias obtenidas en agar PDA fueron inoculadas en los medios Extracto de Levadura Czapek (CYA) (BD Bioxon®, México) y Diclorán Rosa Bengala Cloranfenicol (DRBC) (Difco ${ }^{\mathrm{TM}}$, France) y posteriormente llevadas a incubación a temperatura ambiente durante 5 días en oscuridad. Pasado este tiempo se describió la morfología de las colonias obtenidas y se observaron las estructuras microscópicas con azul de lactofenol (Hycel, México) a 40X. Para la identificación del género y especie de los hongos se consideraron los criterios Dicotómicos de acuerdo a Koneman et al. (2008).

\section{Cuantificación de aflatoxinas totales (AF)}

Previo a la cuantificación de aflatoxinas totales (AF), se realizó una extracción metanólica. Brevemente, se pesaron $5 \mathrm{~g}$ de las muestras y se mezclaron con $25 \mathrm{~mL}$ de metanol al $70 \%$ en una licuadora (Osterizer ${ }^{\circledR}$, USA) durante 3 min. La suspensión obtenida se pasó a través de un papel 
were weighed and mixed with $25 \mathrm{~mL}$ of methanol at $70 \%$ in a blender (Osterizer ${ }^{\circledR}$, USA) for $3 \mathrm{~min}$. The suspension obtained was passed through a filter paper (Whatman ${ }^{\mathrm{TM}}$ No. 1, GE UK) and the resulting solution was diluted with distilled water (1:2).

The quantification was performed by following the manufacturers' recommendations on the ELISA commercial kits for total aflatoxins (RIDASCREEN®FAST Aflatoxin R-Biopharm AG, Germany) with a detection limit of $1.7 \mathrm{ppb}$. Firstly, the samples to be analyzed and $50 \mu \mathrm{L}$ of the standard solution were added to the wells of in the microplate, then, $50 \mu \mathrm{L}$ of the conjugate aflatoxin-enzyme and $50 \mu \mathrm{L}$ of the antibody antitoxin were added. Later, the samples were mixed and incubated for $10 \mathrm{~min}$ at room temperature. Next, the content was emptied on a clean absorbent paper and three washings were realized, adding $250 \mu \mathrm{L}$ of the washing solution into each well. Then, $100 \mu \mathrm{L}$ of the substrate (chromogen) were added into each well and were mixed and incubated for $5 \mathrm{~min}$ in darkness at room temperature. Finally, $100 \mu \mathrm{L}$ of $\mathrm{H}_{2} \mathrm{SO}_{4}$ were added to stop the reaction. The absorbances of the samples were measured at $450 \mathrm{~nm}$ in a microplate reader $(\mathrm{EPOCH} \otimes$, BioTel Instruments, USA). In order to calculate the concentration of $A F$ in the samples, RIDA®SOFT Win software (Germany) (Art. No. Z9999) was used.

\section{Analysis of data}

To compare the frequencies of contamination of the medicinal plants, a chi-squared test was applied using SigmaStat ${ }^{\circledR}$ software (see 3.5) (Jandel Scientific Software, USA).

\section{Results and Discussion}

The consumption of medicinal plants is largely rooted in countries influenced by ancestral cultures; moreover, the lack of access to these systems of institutional health and allopathic medicine, encourages the consumption of these types of products. In addition to this, nowadays the consumption of these types of plants has become popular in all social levels around the world, based on the argument that "natural means innocuous" (Devesa et al., 2004; Enríquez et al., 2005; Marinoff, 2006).

The presence of bacteria and fungi in medicinal plants was demonstrated in this paper, microorganisms that besides being potential pathogens, are indicators of an filtro (Whatman ${ }^{\mathrm{TM}}$ No. 1, GE UK) y la solución resultante se diluyó con agua destilada (1:2).

La cuantificación se realizó siguiendo las especificaciones de los kits comerciales de ELISA para aflatoxinas totales (RIDASCREEN®FAST Aflatoxin, R-Biopharm AG, Germany) con un límite de detección de $1.7 \mathrm{ppb}$. Primeramente, se agregaron $50 \mu \mathrm{L}$ del estándar y las muestras a analizar a los pocillos de la placa, enseguida se agregaron $50 \mu \mathrm{L}$ del conjugado aflatoxina-enzima y $50 \mu \mathrm{L}$ del anticuerpo anti-aflatoxina. Posteriormente, se mezclaron e incubaron las muestras durante $10 \mathrm{~min}$ a temperatura ambiente. A continuación, se vació sobre un papel absorbente limpio y se realizaron tres lavados, adicionando $250 \mu \mathrm{L}$ de solución de lavado a cada pocillo. Después, se agregaron $100 \mu \mathrm{L}$ del substrato (cromógeno) a cada pocillo y se mezclaron e incubaron $5 \mathrm{~min}$ en la oscuridad a temperatura ambiente. Por último, se agregaron $100 \mu \mathrm{L}$ de $\mathrm{H}_{2} \mathrm{SO}_{4}$ para detener la reacción. Las absorbancias de las muestras se midieron a $450 \mathrm{~nm}$ en un lector de microplacas (EPOCH ${ }^{\circledR}$, BioTek Instruments, USA). Para calcular la concentración de AF en las muestras, se utilizó el software RIDA®SOFT Win (Germany) (Art. No. Z9999).

\section{Análisis de datos}

Para comparar las frecuencias de contaminación de las hierbas medicinales se aplicó una prueba de chi cuadrada utilizando el software SigmaStat $\circledast$ (versión 3.5) (Jandel Scientific Software, USA).

\section{Resultados y Discusión}

El consumo de las hierbas medicinales está sumamente arraigado en países con gran influencia de culturas ancestrales; además la falta de acceso a los sistemas de salud institucional y medicina alópata favorece el consumo de este tipo de productos. Aunado a lo anterior, actualmente el consumo de este tipo de plantas se ha popularizado en todos los estratos sociales alrededor del mundo, bajo el argumento de que "lo natural es inocuo" (Devesa et al., 2004; Enríquez et al., 2005; Marinoff, 2006).

En este trabajo se demuestra la presencia de bacterias y hongos en plantas medicinales, microorganismos que además de ser potencialmente patógenos, son indicadores del manejo inadecuado y grado de inocuidad de los productos. Por otra parte, también se evidenció la presencia de aflatoxinas, metabolitos producidos por ciertas especies de hongos, con propiedades carcinogénicas. 
incorrect handling and level of innocuousness of the products. On the other hand, the presence of aflatoxins, metabolites produced by certain species of fungi with carcinogenic properties, was evidenced here. For this study, 28 establishments dedicated to the selling of medicinal plants and located in downtown Tepic, Nayarit were asked to participate; 17 of them accepted to provide information and participate on this research.

According to the data obtained from the surveys, the three most commercialized medicinal plants during autumnwinter period were "gordolobo," also known as common mullein (Verbascum thapsus L.), "eucalyptus" (Eucalyptus mellidora L.) and "hierba del zorrillo" a.k.a. petiveria (Petiveria alliacea L.), which were collected in the period of January-February 2016, while in the period of springsummer, the most commercialized medicinal plants were "cola de caballo" (Equisetum arvense L.), "caña agria" (Costus spicatus L.) and "guámara" (Bromelia pinguin L.) collected in the period of August-September 2016 (Table 1). From the 17 participant stores, according to the existence of plants of the moment of the sampling, 83 samples were collected: 16 of gordolobo, 15 of eucalipto,
Para este estudio, se localizaron 28 establecimientos dedicados a la venta de hierbas medicinales en la zona centro de la ciudad de Tepic, Nayarit, México, de los cuales 17 accedieron a proporcionar información y participar en la presente investigación.

De acuerdo a la información obtenida en las encuestas, las 3 hierbas medicinales de mayor comercialización durante la temporada de otoño-invierno fueron "gordolobo" (Verbascum thapsus L.), "eucalipto" (Eucalyptus melliodora L.) y "hierba del zorrillo" (Petiveria alliacea L.), las cuales se recolectaron en el periodo de enero-febrero de 2016, mientras que en la temporada primavera-verano fueron "cola de caballo" (Equisetum arvense L.), "caña agria" (Costus spicatus L.) y "guámara" (Bromelia pinguin L.) recolectadas en el periodo de agosto-septiembre de 2016 (Tabla 1). De los 17 expendios participantes, de acuerdo a la existencia de hierbas en el momento del muestreo, se colectaron 83 muestras: 16 de gordolobo, 15 de eucalipto, 11 de hierba del zorrillo, 15 de cola de caballo, 15 de caña agria y 11 de guámara.

De las muestras analizadas, $43 / 83$ presentaron contaminación por coliformes totales, 10/83 por coliformes

Table 1

Medicinal herbs of greater marketed in Tepic, Nayarit, Mexico in autumn-winter and spring-summer season.

Tabla 1.

Hierbas medicinales de mayor comercialización en Tepic, Nayarit, México en la temporada otoño-invierno y primavera verano

\begin{tabular}{|c|c|c|c|c|}
\hline Season & Medicinal herbs & $\begin{array}{l}\text { Part of the plant mar- } \\
\text { keted and analyzed }\end{array}$ & $\begin{array}{l}\text { Plant presentation } \\
\text { for sale }\end{array}$ & Therapeutic use ${ }^{*}$ \\
\hline \multirow{3}{*}{ 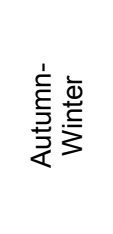 } & $\begin{array}{c}\text { Gordolobo } \\
\text { (V. Thapsus L.) }\end{array}$ & Flowers and leaves & Dry & $\mathrm{RD}$ \\
\hline & $\begin{array}{c}\text { Eucalipto } \\
\text { (E. melliodora L.) }\end{array}$ & Leaves & Dry & $\mathrm{RD}$ \\
\hline & $\begin{array}{l}\text { H. del Zorrillo } \\
(P . \text { alliacea L.) }\end{array}$ & Roots and leaves & Dry & $\mathrm{RD}$ \\
\hline \multirow{3}{*}{ 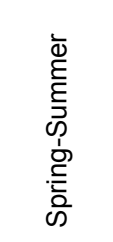 } & $\begin{array}{l}\text { Cola de caballo } \\
\text { (E. arvense L.) }\end{array}$ & Full plant & Fresh & UD \\
\hline & $\begin{array}{c}\text { Caña ágria } \\
\text { (C. spicatus L.) }\end{array}$ & Stem & Fresh & UD \\
\hline & $\begin{array}{c}\text { Guámara } \\
\text { (E. penguin L.) }\end{array}$ & Fruit & Fresh & UD \\
\hline
\end{tabular}

${ }^{*} \mathrm{RD}=$ Respiratory tract diseases; UD= Urinary tract diseases.

${ }^{*} \mathrm{RD}=$ enfermedades del tracto respiratorio; $\mathrm{UD}=$ enfermedades del tracto urinario. 
11 of hierba del zorrillo, 15 of cola de caballo, 15 of caña agria and 11 of guámara.

From the analyzed samples, 43/83 presented contamination by total coliforms, $10 / 83$ by fecal coliforms and $5 / 83$ by $E$. coli. The proportion of positive samples for TC was the following: "cola de caballo" (10/15), "gordolobo" (10/16), "hierba del zorrillo" (7/11), "guámara" (7/11), "eucalipto" 5/15) and "caña agria" (2/15); this last plant presenting less frequency of contamination in comparison to the rest $(p<0.05)$.

As to the contamination by $\mathrm{FC}$, the plant with higher frequency of contamination by these types of bacteria, was "hierba del zorrillo" (4/11), followed by "cola de caballo" (3/15), "gordolobo" (2/16) and "eucalipto" (1/15), while, as for "caña agria" and "guámara," the presence of these bacteria was not detected. On the other hand, the presence of $E$. coli was only detected in samples of "hierba del zorrillo" (4/11) and "gordolobo" (1/16) (Table 2). fecales y $5 / 83$ por $E$. coli. La proporción de muestras positivas para TC fue la siguiente: "cola de caballo" (10/15), "gordolobo" (10/16), "hierba del zorrillo" (7/11), "guámara” (7/11), "eucalipto" (5/15) y "caña agria” (2/15); ésta última planta fue la que presentó menor frecuencia de contaminación en comparación con el resto $(p<0.05)$.

En cuanto a la contaminación por FC, la hierba con mayor frecuencia de contaminación por este tipo de bacterias fue "hierba del zorrillo" (4/11), seguida de "cola de caballo" (3/15), "gordolobo" (2/16) y "eucalipto" (1/15), mientras que en "caña agria" y "guámara" no se detectó presencia de este tipo de bacterias. Por otro lado, la presencia de E. coli solo se detectó en muestras de "hierba del zorrillo" (4/11) y "gordolobo" (1/16) (Tabla 2).

Por lo tanto, los datos obtenidos en el presente trabajo indican que en $51.8 \%$ de las muestras analizadas se detectó la presencia de TC y en $12 \%$ se detectaron FC. Lo anterior indica que las plantas medicinales analizadas no tienen un manejo adecuado o han estado en contacto con materia fecal. La

Table 2.

Microbiological analysis of medicinal herbs of greater marketed in Tepic, Nayarit, Mexico.

Tabla 2.

Análisis microbiológico de hierbas medicinales de mayor comercialización en Tepic, Nayarit, México.

\begin{tabular}{|c|c|c|c|c|c|}
\hline \multirow{2}{*}{ Season } & \multirow{2}{*}{ Medicinal herbs } & \multicolumn{2}{|c|}{ Total coliforms } & \multirow{2}{*}{$\begin{array}{c}\begin{array}{c}\text { Fecal } \\
\text { coliforms }\end{array} \\
\text { PPS }\end{array}$} & \multirow{2}{*}{$\begin{array}{c}\text { E. coli } \\
\text { PPS }\end{array}$} \\
\hline & & PPS & $\begin{array}{c}>10 \\
\text { MPN } / g^{*}\end{array}$ & & \\
\hline \multirow{3}{*}{ 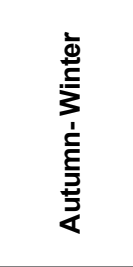 } & $\begin{array}{l}\text { Gordolobo } \\
\text { (V. thapsus L.) }\end{array}$ & $10 / 16$ & $10 / 16$ & $2 / 16$ & $1 / 16$ \\
\hline & $\begin{array}{l}\text { Eucalipto } \\
\text { (E.melliodora L.) }\end{array}$ & $5 / 15$ & $5 / 15$ & $1 / 15$ & ND \\
\hline & $\begin{array}{l}\text { H. del zorrillo } \\
(P . \text { alliacea L.) }\end{array}$ & $7 / 11$ & $7 / 11$ & $4 / 11$ & $4 / 11$ \\
\hline \multirow{3}{*}{ 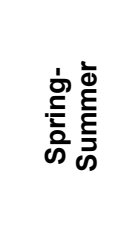 } & $\begin{array}{l}\text { Cola de caballo } \\
\text { (E. arvense L.) }\end{array}$ & $12 / 15$ & $12 / 15$ & $3 / 15$ & ND \\
\hline & $\begin{array}{l}\text { Caña agria } \\
\text { (C. spicatus L.). }\end{array}$ & $2 / 15$ & $2 / 15$ & $0 / 15$ & ND \\
\hline & $\begin{array}{l}\text { Guámara } \\
\text { (B. penguin L.) }\end{array}$ & $7 / 11$ & $4 / 11$ & $0 / 11$ & ND \\
\hline \multicolumn{2}{|c|}{ Total of contaminated samples } & $43 / 83$ & $40 / 83$ & $10 / 83$ & $5 / 83$ \\
\hline
\end{tabular}

PPS $=$ Proportion of positive samples, ${ }^{*}$ proportion of samples with MPN/g>10, ND= Not Detectable.

PPS $=$ Proporción de muestras positivas, ${ }^{*}$ proporción de muestras con MPN/g>10, ND= No detectable. 
Therefore, data obtained in the present work indicated that presence of TC was detected in $51.8 \%$ of the analyzed samples, and FC in $12 \%$ of them. The aforementioned indicates that analyzed medicinal plants were not properly handled or have been in contact with fecal matter. The biological contamination of this type of products can present at different stages throughout their production process (cultivation, harvest, transportation, storing, packaging and point of sales). According to Kneifel et al. (2002), the critical points where a major risk of bacterial contamination exists for this type of products, are during cultivation and harvest.

From the 43 samples with presence of TC, only 3 presented values $\leq 10 \mathrm{MPN} / \mathrm{g}$, which is a limit value of microbiological specifications for tea and infusion of plants (NORMA Oficial Mexicana NOM-218-SSA1.2011; CODEX STAN 192-1995). Therefore, 40 samples were exempt of these specifications, aside from these samples, 9 presented FC and 5 presented contamination by $E$. coli. Therefore it is considered that this type of medicinal plants represents a potential risk for consumers' health. As well, the presence of $\mathrm{FC}$ and $E$. coli in this type of samples evidenced the possibility that other etiological agents of infections for human beings, such as Shigella and Salmonella, among others, could be present.

With respect to the determination of fungi, from the 6 types of plants analyzed, 5 resulted multi-contaminated by more than one species of fungi. "Gordolobo" and "cola de caballo" were the plants with the most mycotic contamination ( 5 genera of fungi of each one), followed by "caña agria" (4 genera), "eucalipto" (3 genera) and "hierba del zorrillo" (2 genera), while "guámara" was only contaminated by one type of fungus. Fungus genus the most frequently found in the analyzed plants was Aspergillus spp (24/83), followed by Penicillum spp (19/83), Rhizopus spp (19/83), Mucor spp (4/83), Paecilomyces spp (3/83), Fusarium spp (2/83) and Alternaria spp (2/83) (Table 3). This way, the most frequent fungi in the analyzed samples were Aspergillus, Penicillium and Rhizopus ( $p<0.001)$, compared to the rest of the genera identified.

Due to the fact that Aspergillus genus is a potent producer of aflatoxins, its species were identified. From the 24 samples contaminated by this fungus, $A$. niger was isolated in 19 samples, $A$. fumigatus in 3 and $A$. terreus in 2 (Table 4). contaminación biológica en este tipo de productos puede presentarse en diferentes fases a lo largo de su proceso de producción (cultivo, cosecha, transporte, almacenamiento, empaque y puntos de ventas). De acuerdo con Kneifel et al. (2002) los puntos críticos en donde existe un mayor riesgo de contaminación microbiana para este tipo de producto, son durante el cultivo y cosecha.

De las 43 muestras con presencia de TC, solo 3 presentaron valores $\leq 10 \mathrm{MPN} / \mathrm{g}$, el cuál es un valor límite de especificaciones microbiológicas para té e infusiones de hierbas (NORMA Oficial Mexicana NOM-218-SSA1-2011; CODEX STAN 192-1995). Por lo tanto, 40 muestras están fuera de estas especificaciones, además de estas muestras, 9 presentaron FC y 5 presentaron contaminación por E.coli. Por lo cual se considera que este tipo de hierbas medicinales representan un riesgo potencial para la salud del consumidor. Así mismo, la presencia de FC y E.coli en este tipo de muestras evidencian la posibilidad de que estén presentes otros agentes etiológicos de infecciones para el ser humano, tales como Shigella y Salmonella entre otros.

Con respecto a la determinación de hongos, de los 6 tipos de hierbas analizadas, 5 resultaron multicontaminadas por más de una especie de hongo. "Gordolobo" y "cola de caballo" fueron las hierbas con mayor contaminación micótica (5 géneros de hongos cada una), seguida de "caña agria" (4 géneros), "eucalipto" (3 géneros) y "hierba del zorrillo" (2 géneros), mientras que "guámara" sólo estuvo contaminada por un tipo de hongo. El género de hongo que se encontró con mayor frecuencia en las hierbas analizadas fue Aspergillus spp (24/83), seguido de Penicillum spp (19/83), Rhizopus spp (19/83), Mucor spp (4/83), Paecilomyces spp (3/83), Fusarium spp (2/83) y Alternaria spp (2/83) (Tabla 3). De esta manera, los hongos más frecuentes en las muestras analizadas fueron Aspergillus, Penicillium y Rhizopus $(p<0.001)$, comparado con el resto de los géneros identificados.

Debido a que el género Aspergillus es un potente productor de aflatoxinas, se identificaron sus especies. De las 24 muestras contaminadas por este hongo, en 19 muestras se aisló $A$. niger, en 3 muestras $A$. fumigatus y en 2 muestras A. terreus (Tabla 4).

En un reporte sobre hierbas medicinales realizado por Bugno et al. (2006), en Sao Paulo Brasil, encontraron que más del $50 \%$ de las muestras estuvieron contaminadas por diversos hongos, pasando el límite permitido por la farmacopea de los Estado Unidos. La carga dominante fue 
Table 3.

Fungi found in medicinal herbs of greater marketed in Tepic, Nayarit, Mexico.

Tabla 3.

Hongos encontrados en hierbas medicinales de mayor comercialización en Tepic, Nayarit, México.

\begin{tabular}{|c|c|c|c|c|c|c|c|c|}
\hline \multirow[b]{2}{*}{ Season } & \multirow[b]{2}{*}{$\begin{array}{l}\text { Medicinal } \\
\text { herbs }\end{array}$} & \multicolumn{7}{|c|}{$N^{\circ}$ of samples contaminated by fungi } \\
\hline & & $\begin{array}{l}\text { Aspergillus } \\
\text { spp }\end{array}$ & $\begin{array}{l}\text { Penicillum } \\
\text { spp }\end{array}$ & $\begin{array}{l}\text { Fusarium } \\
\text { spp }\end{array}$ & $\begin{array}{l}\text { Alternaria } \\
\text { spp }\end{array}$ & $\begin{array}{l}\text { Rhizopus } \\
\text { spp }\end{array}$ & Mucor spp & $\begin{array}{l}\text { Paecilomy- } \\
\text { ces spp }\end{array}$ \\
\hline \multirow{3}{*}{ 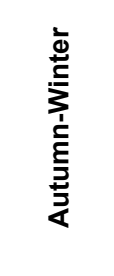 } & $\begin{array}{l}\text { Gordolobo } \\
\text { (V. thapsus L.) }\end{array}$ & $8 / 16$ & $6 / 16$ & ND & ND & $5 / 16$ & $2 / 16$ & $1 / 16$ \\
\hline & $\begin{array}{l}\text { E u c a I i p t o } \\
\text { (E.melliodora L.) }\end{array}$ & $3 / 15$ & $1 / 15$ & ND & ND & ND & $1 / 15$ & ND \\
\hline & $\begin{array}{l}\text { H. del zorrillo } \\
\text { (P. alliacea L.) }\end{array}$ & ND & ND & $1 / 11$ & ND & ND & $1 / 11$ & ND \\
\hline \multirow{3}{*}{ 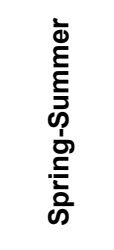 } & $\begin{array}{l}\text { Cola de caballo } \\
\text { (E. arvense L.) }\end{array}$ & $7 / 15$ & $7 / 15$ & $1 / 15$ & $1 / 15$ & $6 / 15$ & ND & $2 / 15$ \\
\hline & $\begin{array}{l}\text { Caña agria } \\
\text { (C. spicatus L.). }\end{array}$ & $6 / 15$ & $5 / 15$ & ND & $1 / 15$ & $3 / 15$ & ND & ND \\
\hline & $\begin{array}{l}\text { Guámara } \\
\text { (B. penguin L.) }\end{array}$ & ND & ND & ND & ND & $5 / 11$ & ND & ND \\
\hline
\end{tabular}

${ }^{*} \mathrm{ND}=$ Not detectable

${ }^{*} \mathrm{ND}=$ No detectable.

Table 4.

Species of Aspergillus identified in medicinal herbs of greater marketed in Tepic, Nayarit, Mexico.

Tabla 4.

Especies de Aspergillus identificados en hierbas medicinales de mayor comercialización en Tepic, Nayarit, México.

\begin{tabular}{|c|c|c|c|c|}
\hline Season & Medicinal herbs & A. niger & A. terreus & A. fumigatus \\
\hline \multirow{3}{*}{ 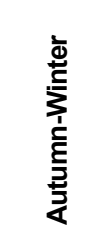 } & Gordolobo (V. thapsus L.) & 6 & 1 & 1 \\
\hline & Eucalipto (E. melliodora L.) & 3 & ND & ND \\
\hline & H. del zorrillo (P. alliacea L.) & ND & ND & ND \\
\hline \multirow{3}{*}{ 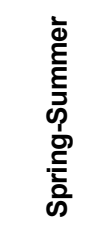 } & C. de caballo (E. arvense L.) & 5 & 1 & 1 \\
\hline & Caña agria (C. spicatus L.). & 5 & ND & 1 \\
\hline & Guámara (B. penguin L.) & ND & ND & ND \\
\hline \multicolumn{2}{|r|}{ Total of contaminated herbs } & 19 & 2 & 3 \\
\hline
\end{tabular}

${ }^{*} \mathrm{ND}=$ Not detectable

${ }^{*} \mathrm{ND}=$ No detectable 
In a report about medicinal plants realized by Bugno et al. (2006), in Sao Paulo, Brazil, they found that more than $50 \%$ of the samples were contaminated by diverse fungi, exceeding the limit allowed by the pharmacopoeia of the United States. The dominant load was Aspergillus followed by Penicillum, which were similar results to those found in this study (Bugno et al., 2006). Other reports have also demonstrated that in medicinal plants, the genera Penicillum, Aspergillus niger and Fusarium can be found more frequently (Abou-Arab et al., 1999), being these genera considered as storage fungi, since during this stage, the possibility of its incidence increases, due to the fact that its growth mainly depends on temperature and relative humifity (Rodríguez-Tito et al., 2012).

Aspergillus is a potent producer of mycotoxins, therefore when identifying the species in the analyzed samples, and when finding A. niger (present in 19 of 24 samples), followed by $A$. fumigatus (present in 3 of 24 samples) and $A$. terreus (found in 2 of 24 samples), it suggested that the environmental conditions of storing of the medicinal plants were proper for the growth of these fungi and the production of its toxins. Similar studies demonstrated that the species of Aspergillus genus potentially mycotoxic were: flavus, parasiticus, ochraceus niger and fumigatus (Bugno et al., 2006). However, About-Arab et al. (1999), found only the species $A$. ochraceus and $A$. niger with the capacity of producing mycotoxins in medicinal plants.

With respect to the determination of aflatoxins, the results indicated that from the 83 analyzed samples, 37 were positive (44.6\%). From these 37 positive samples, 18 (21.7 $\%)$ presented levels above the allowed limits (>20ppb) (FAO, 2003). In this sense, the samples of "eucalipto" (100\%) and "gordolobo" (93.8\%) were the plants with the highest quantity of AF, followed by "cola de caballo" (26.6 \%), "caña agria" (13.3\%) and "hierba del zorrillo" (9\%), while in the samples of "guámara," no presence of AF was detected (Table 5). When analyzing the frequency of positive samples for this group of mycotoxins, the statistical analysis indicated higher frequency for this type of contaminant in "eucalipto" and "gordolobo" $(p<0.001)$ in comparison to rest of analyzed plants.

Studies carried out by Bugno et al. (2006) found specifically that $27.6 \%$ of $A$. flavus has the capacity of producing $A F B_{1} \circ A F B_{1}+B_{2}$, while $45.5 \%$ of $A$. parasiticus has the capacity of producing $A F B_{1}, B_{2}, G_{1}$ and $G_{2}$, which
Aspergillus seguido de Penicillum, los cuales son resultados similares a los encontrados en este estudio (Bugno et al., 2006). Otros reportes, también han demostrado que en plantas medicinales pueden encontrarse con mayor frecuencia los géneros Penicillum, Aspergillus niger y Fusarium (Abou-Arab et al., 1999). Siendo estos géneros considerados como hongos de almacenamiento, por lo que, durante esta etapa, puede aumentar las posibilidades de su aparición, debido a que su crecimiento depende principalmente de temperatura y humedad relativa (Rodríguez-Tito et al., 2012).

Aspergillus es un potente productor de micotoxinas, por lo que, al identificarse las especies en las muestras analizadas, y encontrarse $A$. niger (presente en 19 de 24 muestras), seguido de $A$. fumigatus (presente en 3 de 24 muestras) y $A$. terreus (presente en 2 de 24 muestras), sugiere que las condiciones ambientales de almacenamiento de las hierbas medicinales eran propicias para el crecimiento de estos hongos y la producción de sus toxinas. Estudios similares demostraron que las especies del género Aspergillus potencialmente micotóxicas son: flavus, parasiticus, ochraceus, niger y fumigatus (Bugno et al., 2006). Sin embargo, Abou-Arab et al. (1999), encontraron únicamente las especies $A$. ochraceus y $A$. niger con capacidad de producir micotoxinas en plantas medicinales.

Con respecto a la determinación de aflatoxinas, los resultados indicaron que, de las 83 muestras analizadas, 37 fueron positivas (44.6\%). De éstas, 18 (21.7\%) presentaron niveles por arriba de los límites permisibles (>20ppb) (FAO, 2003). En este sentido, las muestras de "eucalipto" (100\%) y "gordolobo" (93.8 \%) fueron las hierbas con mayor cantidad de AF, seguidas de "cola de caballo" (26.6\%), "caña agria" (13.3 \%) y "hierba del zorrillo" (9\%), mientras que en las muestras de "guámara" no se detectó presencia de AF (Tabla 5). Al analizar la frecuencia de muestras positivas para este grupo de micotoxinas, el análisis estadístico indicó mayor frecuencia de este tipo de contaminante en "eucalipto" y "gordolobo" $(p<0.001)$ en comparación con el resto de las plantas analizadas.

Estudios realizados por Bugno et al. (2006) encontraron específicamente que el $27.6 \%$ de $A$. flavus tiene la capacidad de producir $\mathrm{AFB}_{1} \circ \mathrm{AFB}_{1}+\mathrm{B}_{2}$, mientras que el $45.5 \%$ de $A$. parasiticus tiene la capacidad de producir $A F B_{1}, B_{2}, G_{1}$ y $G_{2}$ lo que demuestra que la presencia de hongos implica un riesgo potencial para la producción de micotoxinas, especialmente durante el almacenaje prolongado en condiciones inadecuadas 
Table 5 .

Quantification of total aflatoxins in samples of medicinal herbs of greater marketed in Tepic, Nayarit, Mexico.

Tabla 5.

Cuantificación de aflatoxinas totales en muestras de hierbas medicinales de mayor comercialización en Tepic, Nayarit, México

\begin{tabular}{|c|c|c|c|c|c|}
\hline Season & Medicinal herbs & Positive samples & $\begin{array}{l}\text { Contaminated } \\
\text { samples } \\
\text { (>20 ppb) }\end{array}$ & $\overline{\mathbf{x}}$ & Range \\
\hline \multirow{3}{*}{  } & $\begin{array}{l}\text { Gordolobo } \\
\text { (V. thapsus L.) }\end{array}$ & $15 / 16$ & $2 / 15$ & 26.34 & $5.6-37.2$ \\
\hline & $\begin{array}{l}\text { Eucalipto } \\
\text { (E. melliodora L.) }\end{array}$ & $15 / 15$ & $14 / 15$ & 250.75 & $2.13-960.1$ \\
\hline & $\begin{array}{l}\text { H. del zorrillo } \\
\text { (P. alliacea L.) }\end{array}$ & $1 / 11$ & $0 / 1$ & - & - \\
\hline \multirow{3}{*}{ 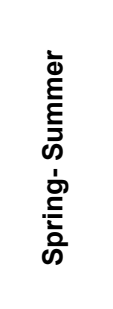 } & $\begin{array}{l}\text { Cola de caballo } \\
\text { (E. arvense L.) }\end{array}$ & $4 / 15$ & $2 / 4$ & 21 & $4.94-41.76$ \\
\hline & $\begin{array}{l}\text { Caña agria } \\
\text { (C. spicatus L.). }\end{array}$ & $2 / 15$ & $0 / 2$ & 2,61 & $2.45-2.78$ \\
\hline & $\begin{array}{l}\text { Guámara } \\
\text { (B. penguin L.) }\end{array}$ & ND & - & - & - \\
\hline & Total & 37 & 18 & - & - \\
\hline
\end{tabular}

${ }^{*} \mathrm{ND}=$ Not detectable

${ }^{*} \mathrm{ND}=$ No detectable

demonstrated that the presence of fungi involved a potential risk for the production of mycotoxins, especially during prolonged storage in inadequate conditions and without temperature control. In this sense, obtained data in this work, pointed out that the number of samples of "gordolobo" and "eucalipto" contaminated by Aspergillus genus is lower with respect to the number of positive samples for total AF. These data suggested that the chemical components like the essential oils present in "gordolobo" and "eucalipto" can inhibit the growth of fungi. There are studies performed with the extract of essential oil of "eucalipto," where the inhibition of growth of Aspergillus section flavi (A. parasiticus and A. flavus) was observed (Kneifel et al., 2002; Elshafie et al., 2002; Bluma et al., 2008).

\section{Conclusion}

The present research demonstrated the presence of biological contaminants (coliforms bacteria, y sin control de temperatura. En este sentido, los datos obtenidos en este trabajo, señalan que el número de muestras de "gordolobo" y "eucalipto" contaminadas por el género Aspergillus es menor respecto al número de muestras positivas para AF totales. Estos datos sugieren, que los componentes químicos como los aceites esenciales presentes en "gordolobo" y "eucalipto" pueden inhibir el crecimiento fúngico. Existen estudios realizados con extracto de aceite esencial de "eucalipto", donde se observó la inhibición del crecimiento de Aspergillus sección flavi (A. pasasiticus y A. flavus) (Kneifel et al., 2002; Elshafie et al., 2002; Bluma et al., 2008).

\section{Conclusión}

La presente investigación demuestra la presencia de contaminantes biológicos (bacterias coliformes, hongos y micotoxinas) en hierbas medicinales con potencial 
fungi and mycotoxins) in medicinal plants with infectious, toxic and in extreme cases, carcinogenic potential. Therefore it is indispensable that competent authorities effectively and strictly regulate the selling process of these products, but also their processes of cultivation, harvest, and storage, which are critical points to ensure their innocuousness. infeccioso, tóxico y en casos extremos carcinogénicos. Por lo que es indispensable que las autoridades competentes regulen de manera estricta el proceso no sólo de venta de estos productos, sino también los procesos de cultivo, cosecha y almacenamiento de los mismos, puntos críticos para asegurar su inocuidad.

\section{References}

Abou-Arab, A. A. K., Soliman Kawther, M., El Tantawy, M. E., Badeaa, R. I and Khayria, N. (1999). Quantity estimation of some contaminants in commonly used medicinal plants in the Egyptian market. Food Chemistry, 67(4): $357-$ 363. https://dx.doi.org/10.1016/S0308-8146(99)00082-5

Arias, M. L., Chaves, C. and Alfaro, L. D. (1999). Análisis microbiológico de algunas infusiones de hierbas medicinales. Revista Biomédica. 10:1-6. https://doi.org/10.32776/revbiomed.v10i1.181

Ávila Martínez, C. J. (2017). La medicina tradicional en la pobreza. Revista de Comunicación y Salud. 7:199-204. https:// dialnet.unirioja.es/servlet/articulo?codigo $=6365835$

Bluma, R., Amaiden, M. R. and Etcheverry, M. (2008) Screening of Argentine plant extracts: Impact on growth parameters and aflatoxin B1 accumulation by Aspergillus section Flavi. International Journal of Food Microbiology, 122: 114-125. https://dx.doi.org/10.1016/j.ijfoodmicro.2007.11.050

Bugno, A., Buzzo Almodovar, A. A., Caldas Pereira, T., Andreoli Pinto, T. J., Sabino M. (2006). Occurrence of toxigenic fungi in herbal drugs. Brazilian Journal of Microbiology, 37: 47-51. https://dx.doi.org/10.1590/S151783822006000100009

Bye, R. A. Jr. and Linares, E. (1990). Mexican Market Plants of $16^{\text {th }}$ Century. I. Plants recorded in Historia Natural de Nueva España. Journal of Ethnobiology. 10(2): 151-168. https://ethnobiology.org/sites/default/files/pdfs/JoE/102/ByeJrLinares.pdf

CCAYAC-M-004/11. Método de Prueba para la estimación de la densidad microbiana por la técnica del número más probable (NMP), detección de Coliformes Totales, Coliformes Fecales y Escherichia coli. https://www.academia. edu/22317697/CCAYAC-M-004 11 metodo de prueba para la estimacion de la densidad microbiana por la tecnica del numero mas probable nmp deteccion de coliformes totales coliformes fecales y Escherichia coli

Codex Alimentarius (1995). Norma general para los aditivos alimentarios. Norma internacional de los alimentos. CODEX STAN 192-1995. http://www.fao.org/gsfaonline/docs/CXS 192s.pdf

Codex Alimentarius Commission (2014). Report of the forty-fifth session of the codex committee on food hygiene. FAO/WHO Food Standards Programme. REP14/FH. http://www.fao.org/news/story/en/item/238558/icode/

da-Silva, L. S. C., Oliveira de Arruda, G., Dias, R. R., and Martins, A. M. R. (2012). Representaciones y usos de las plantas medicinales en mayores. Revista Latino-Americana de Enfermagem. 20(4): [09 pantallas]. http://www.scielo.br/ pdf/rlae/v20n4/es 19.pdf

Devesa, J. F., Pellicer B. J., Ferrando G. J., Borghol, H. A., Bustamante B. M., Ortuño C. J., Ferrando, M. I., Llobera, B. C., Sala, L. A., Miñana, M. M., Nolasco, B. A. and Fresquet, F. J. L. (2004). Consumption of medicinal herbs in patients attending a gastroenterology outpatient clinic. Gastroenterología y Hepatología, 27(4): 244-249. https:// dx.doi.org/10.1016/s0210-5705(03)70453-1

Elshafie, A. E., Al-Rashdi, T. A., Al-Bahry, S. N. and Bakheit, C. S. (2002). Fungi and aflatoxins associated with spices in the Sultanate of Oman. Mycopathologia. 155: 155-160. https://dx.doi.org/10.1023/A:1020427527963

Enríquez Rubio, E., Frati Munari, A. C. and González Pier, E. (2005). Hacia una Política Farmacéutica Integral para México. Primera edición. SSA:49-51.Government Document99. http://apps.who.int/medicinedocs/documents/ s19898es/s19898es.pdf

FAO (Food and Agriculture Organization of United Nations) (2003). FAO corporate repository, Economic and Social Department Worlwide regulations for mycotoxins in food and feed in 2003. Mycotoxin regulations in 2003 and 
current developments. pp. 1-20. http://www.fao.org/3/y5499e/y5499e00.htm

Gómez Castellanos, J. R. (2009). El ambiente regulatorio de los medicamentos herbolarios en México. Antecedentes, situación actual y perspectivas al año 2025. Boletín Latinoamericano y del Caribe de Plantas Medicinales y Aromáticas: 8(1): 33-40. https://www.redalyc.org/html/856/85680107/

Martins, J. and S, B. (2018). Phytochemistry and pharmacology of anti-depressant medicinal plants: A review. Biomedicine \& Pharmacotherapy, 104: 343-365. https://dx.doi.org/10.1016/i.biopha.2018.05.044

Juárez-Rosete, C. R., Aguilar-Castillo, J. A., Juárez-Rosete, M. E., Bugarín-Montoya, R., Juárez-López, P. and, CruzCrespo, E. (2013). Herbs and medicinal plants in mexico: tradition \& innovation. Revista Bio Ciencias. 2(3): 119-129. http://dspace.uan.mx:8080/jspui/handle/123456789/731

Kabak, B., and Dobson, A. D. W. (2015). Mycotoxins in spices and herbs-An update. Critical Reviews in Food Science and Nutrition. 57(1): 18-34. https://dx.doi.org/10.1080/10408398.2013.772891

Kishan, P. S., Bhattacharya, S. and Sharma, P. (2014). Assessment of heavy metal contents of some Indian medicinal plants. American-Eurasian Journal of Agriculture \& Environmental Sciences. 14(10): 1125-1129. https://pdfs. semanticscholar.org/ae35/ca48857652ed1dfe2a76d955ceb82cd0c222.pdf

Kneifel, W., Czech, E. and Kopp, B. (2002). Microbial contamination of medicinal plants. A review. Planta Medica, 68(1): 5-15. https://dx.doi.org/10.1055/s-2002-20060

Koneman, E., Procop, G., Schrenckenberge, P., Woods, G., Janda, W., Allen, S. and Winn, W. (2008). Diagnóstico microbiológico, Sexta edición. Buenos Aires-Argentina. Médica Panamericana.

Kumar, N., Kumar, S., Bauddh, K., Dwivedi, N., Shukla, P., Singh, D.P. and Barman, S. C. (2015). Toxicity assessment and accumulation of metals in radishirrigated with battery manufacturing industry effluent. International Journal of Vegatable Science. 21(4): 373-383. https://dx.doi.org/10.1080/19315260.2014.880771

Luitel, D.R., Rokaya, M.B., Timsina, B. and Münzbergová Z. (2014). Medicinal plants used by the Tamang community in the Makawanpur district of central Nepal. Journal of Ethnobiology and Ethnomedicine. 10:5. https://dx.doi. org/10.1186/1746-4269-10-5

Marinoff, M. (2006). Las plantas medicinales desde la Biblia a la actualidad. Comunicaciones científicas y Tecnológicas. http://www.revistacyt.unne.edu.ar/unnevieja/Web/cyt/cyt2006/08-Exactas/2006-E-053.pdf

Marinoff, M. A., Martínez, J. L. and Urbina, M.A. (2009). Precauciones en el empleo de plantas medicinales. Boletín Latinoamericano y del Caribe de Plantas Medicinales y Aromáticas. 8(3): 184-187. https://www.redalyc.org/ html/856/85611774014/

Marroquín-Cardona, A. G., Johnson, N. M., Phillips, T. D., and Hayes, A. W. (2014). Mycotoxins in a changing global environment-Areview. Food and Chemical Toxicology. 69: 220-230. https://dx.doi.org/10.1016/i.fct.2014.04.025

Momoh, A. R. M., Orhue, P. O., Idonije, O. B., Oaikhena, A. G., Nwoke, E. O. and Momoh, A. A. (2011). The antibiogram types of Escherichia coli isolated from suspected urinary tract infection samples. Journal of Microbiology and Biotechnology Research. 1(3): 57-65. https://imbronline.com/index.php/JMBR/article/view/33

NOM-110-SSA1-1994, Bienes y servicios. Preparación y dilución de muestras de alimentos para su análisis microbiológico. http://www.salud.gob.mx/unidades/cdi/nom/110ssa14.html

NOM-111-SSA1-1994, Bienes y servicios. Método para la cuenta de mohos y levaduras en alimentos. http://www.salud.gob. mx/unidades/cdi/nom/111ssa14.html

NOM-218-SSA1-2011, Productos y servicios. Bebidas saborizadas no alcohólicas, suscongelados, productos concentrados para prepararlas y bebidas adicionadas con cafeína. Especificacione sy disposiciones sanitarias. Métodos de prueba. http://www.salud.gob.mx/cdi/nom/compi/NOM-218-SSA1-2011.pdf

Pemán, J. and Quindós, G. (2016). Current aspects of invasive diseases caused by Candida and other yeast fungi. Revista Iberoamericana de Micología. 33(3): 133-139. https://dx.doi.org/10.1016/j.riam.2015.10.001

Pullés, M. R. (2014). Microorganismos indicadores de la calidad del agua potable en cuba. Revista CENIC Ciencias Biológicas. 45(1): 25-36. http://www.redalyc.org/articulo.oa?id=181230079005.

Rodrigues, A. A. Z., De Queiroz, M. E. L. R., De Oliveira, A. F., Neves, A. A., Heleno, F. F., Zambolim, L., Freitas, J.F. and Morais, E. H. C. (2017). Pesticide residue removal in classic domestic processing of tomato and its effects on product quality. Journal of Environmental Science and Health. Part B 52(12): 850-857. https://dx.doi.org/10.10 $\underline{\text { 80/03601234.2017.1359049 }}$ 
Rodríguez-Tito, J. C., Puente-Zapata, E., Marín-Sánchez, D., Pérez-Garrido, N., Ferrer-Salas, D. and Cedeño-Soularit, N. (2012). Aspergillus sp. y aflatoxinas en plantas medicinales y Té Comercial. Boletín Latinoamericano y del Caribe de Plantas Medicinales y Aromáticas. 11(3): 218-222. https://www.redalyc.org/pdf/856/85622739003.pdf

Sánchez, V., González, A. M. and Lurá, M. C. (2006). Análisis Microbiológico de Hierbas Medicinales y su Contaminación por Especies de Aspergillus Toxicogénicos. Acta Farmacéutica Bonaerense. 25(1): 89-94. http://www.latamjpharm. org/trabajos/25/1/LAJOP 2511114 26OS1F3WJ3.pdf

World Health Organization (WHO) (2004). New WHO guidelines to promote proper use of alternative medicine. Geneva, Switzerland. 